\title{
Living in the southwest Portuguese coast during the Late Mesolithic: The case study of Vale Marim I
}

\author{
Joaquina Soares*, Carlos Tavares da Silva \\ UNIARQ-Archaeological Centre of the University of Lisbon and MAEDS - Museum of Archaeology and Ethnography of the Setúbal District/AMRS, Av. Luísa Todi, 162, \\ 2900-451 Setúbal, Portugal
}

\section{A R T I C L E I N F O}

\section{Keywords:}

Southwest Portuguese coast

Late Mesolithic

Dwelling structures

Smoked fish

Shellfish harvesting

\begin{abstract}
A B S T R A C T
The Mesolithic base-camp of Vale Marim I is located on the seashore of Sines harbour domain and covers a surface of about 1 ha. The archaeological excavation encompassed an area of about $260 \mathrm{~m}^{2}$. Several domestic structures were recovered; the fireplaces probably polarized economic and social action, like manufacture of lithic artefacts, cooking and probably the fish smoking activity; some areas without domestic structures and with very low density of lithic artefacts have been interpreted as latent remains of probable huts. The idea of a society based on an incipient kinship structure is admitted. The charcoal analysis has provided substantial information on the spread of pinewood (Pinus pinea) in keeping with a progressively mild climate, in the transition to the sixth millennium cal BC, favouring the development of open-air settlements. In sum, dwelling structures will be discussed in accordance with environmental changes and social organization.
\end{abstract}

\section{Introduction}

This paper focuses on the site of Vale Marim I, especially on its dwelling structures. We have based our approach on the assumption that the spatial relations between domestic structures and their conjugation with the patterns of artefact distributions can yield valuable information on social life. The concept of taskscape (Ingold, 1993, 2000) and the interpretation model used by Leroi-Gourhan and Brézillon (1972) at the Magdalenien habitat of Pincevent underlie this proposal, bearing in mind the anthropological studies of current hunter societies (Binford, 1983; GrØn, 2015). The information about the domestic structures of the coeval base-camp of Moita do Sebastião (Roche, 1960) is an important reference to Vale Marim I.

In spite of the very long history of research on the Tagus and Sado Mesolithic sites (referred in the Portuguese literature as "concheiros") that take off respectively in 1863 (Costa, 1865; Ribeiro, 1884) and 1936 (Barradas, 1936), the spatial organization of the inhabited areas of the Mesolithic is so far virtually unknown; the burials were the main goal of the fieldwork, not cemeteries as a whole or the less impressive domestic structures. The first known Mesolithic sites of the southwest coast were discovered and reported by the authors in 1981 (Tavares da Silva and Soares, 1981). In 1983, a rescue and large archaeological excavation was headed by the authors in the Mesolithic site of Vale Marim I, inside the Sines harbour domain (Fig. $1 \mathrm{~A}, \mathrm{n}^{\circ} 30$ ) that revealed a high concentration of domestic structures presented in this paper. They are compared with the most extense, well preserved and contextualized ensemble of dwelling structures from Southern Portugal, recovered at the coeval site of Moita do Sebastião (Cardoso, 2007), on the left bank of the Muge stream (about $3 \mathrm{~km}$ far from its confluence with the Tagus River) (Fig. $1 \mathrm{~A}, \mathrm{n}^{\circ}$ 5). The site was excavated under the direction of Jean Roche (Roche, 1960) between 1952 and 1954, and in the lower layer it revealed a series of 61 post holes defining a frame for a semicircular hut with about 7-8 $\mathrm{m}$ in diameter, facing south (Fig. 2A); there were also storage and garbage pits, remains of hearths and burnt clay with impressions of branches derived from domestic structures, as well as a great density of lithic artefacts. After this first occupational event, the area was submitted to the funerary function (Fig. 2B). This phase is radiocarbon dated between 6030 and $5300 \mathrm{cal} \mathrm{BC}$, at 2 sigma (Martins et al., 2008).

The Mesolithic occupation of the Tagus and Sado palaeo-estuaries (Fig. 1A) began about $6200 \mathrm{cal}$ BC (Martins et al., 2008; Bicho et al., 2010; Soares, 2016), partially overlapping the end or immediately after the 8.2 ka cold event (Alley and Agustsdottir, 2005), when the ocean rise reset, although in a less accelerated rate onward and the estuaries progressively entered a dynamics of sedimentation (Van der Schriek, 2004; Van der Schriek et al., 2008; Freitas and Andrade, 2008). A geoarchaeological survey in the palaeo-Sado estuary (Vale de Guizo) showed that about $10 \mathrm{~m}$ of sediments were deposited after $6450 \mathrm{cal}$ BC (Costa et al., 2015; communication by Diniz et al., 2016). The maximum saltwater influence in the Muge valley was registered at $5500 \mathrm{cal}$

\footnotetext{
* Corresponding author

E-mail address: cea.maeds@amrs.pt (J. Soares).
} 
A

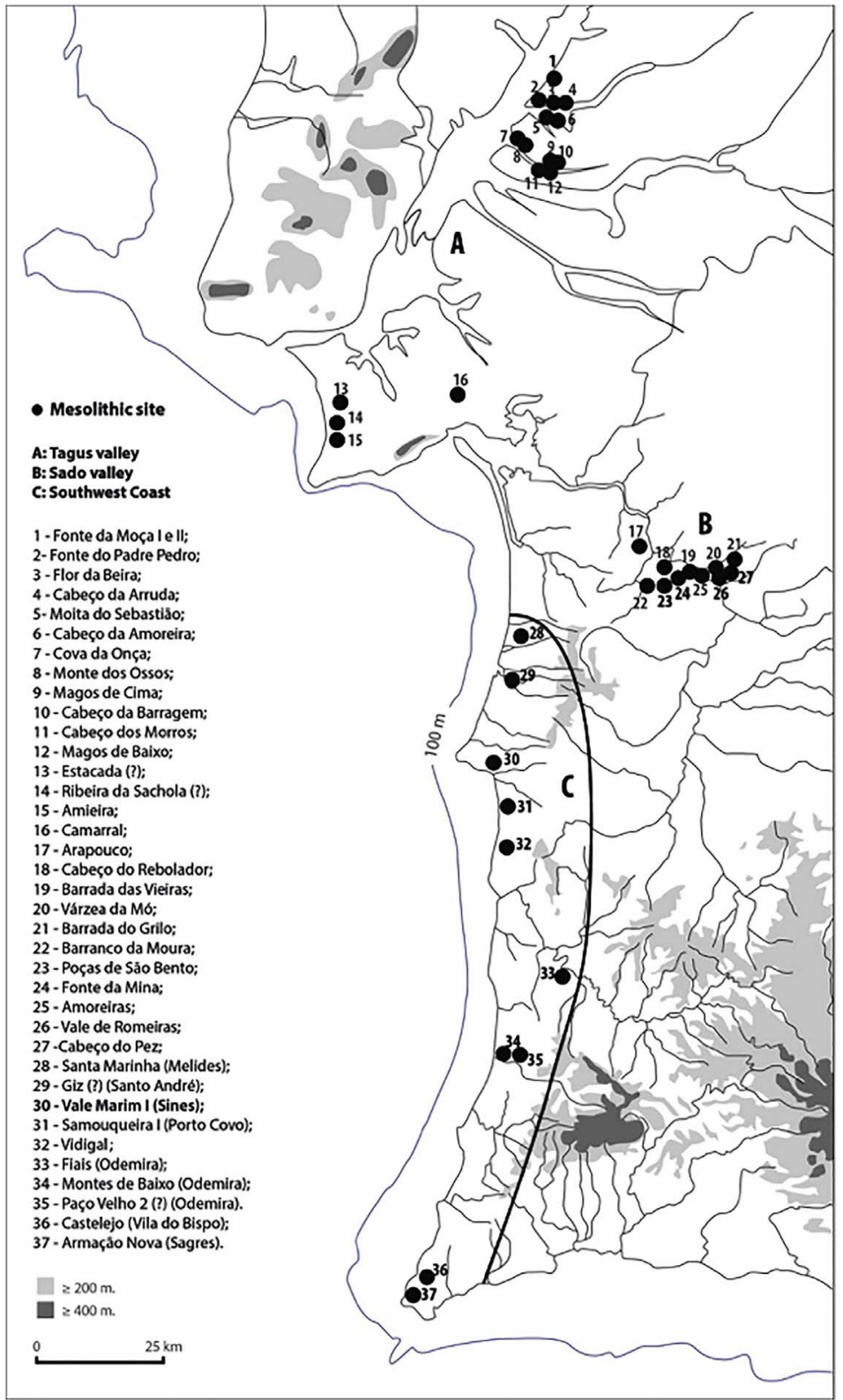

B

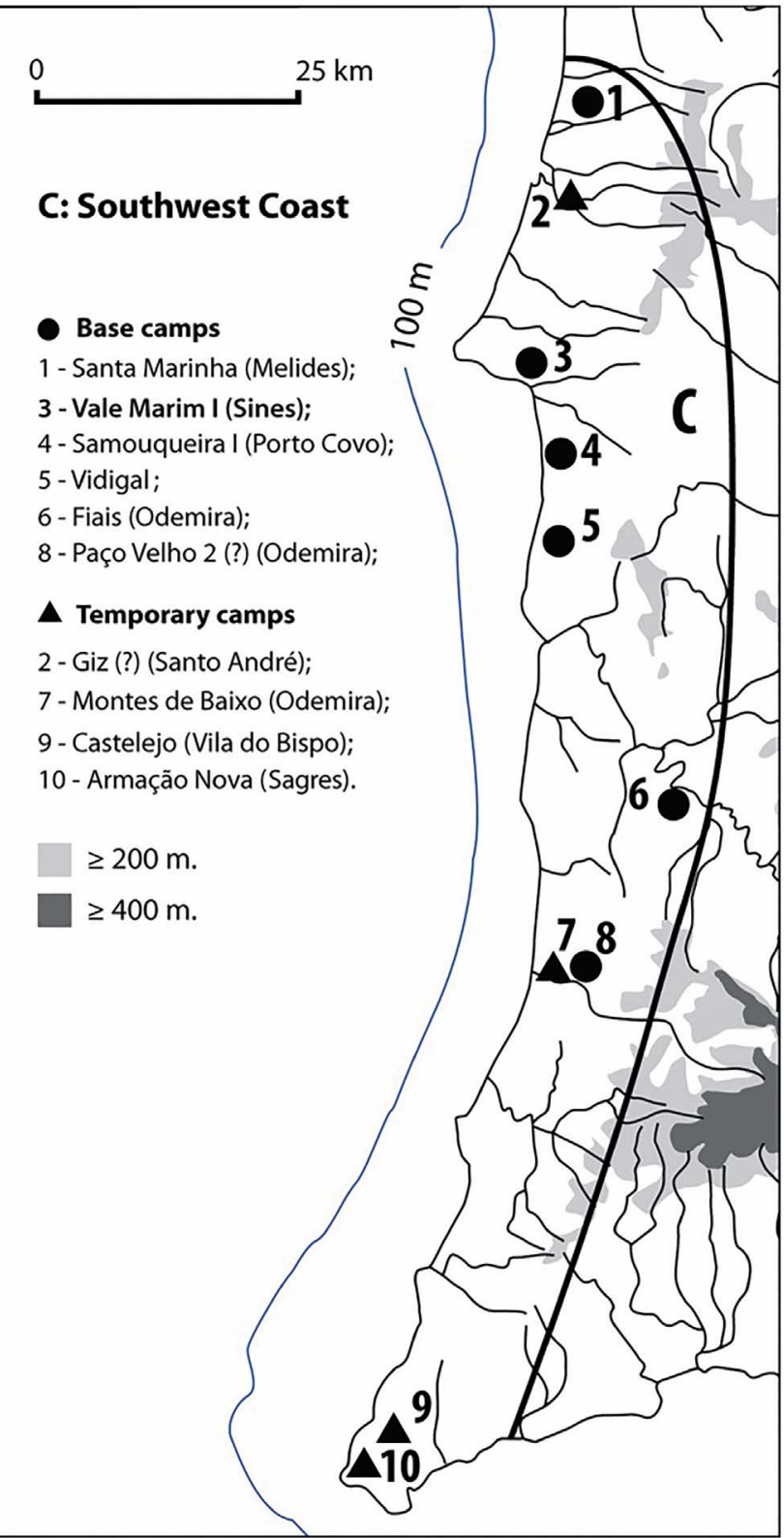

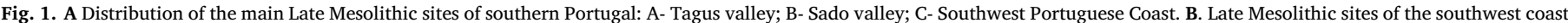

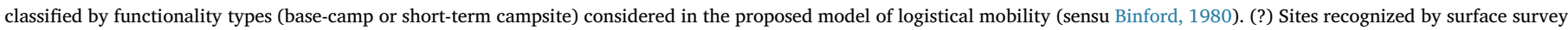
but still waiting for confirmation through archaeological excavation.

BC as indicated by the peak of foraminifera (Van der Schriek et al., 2008). In the Late Mesolithic of the Tagus and Sado palaeo-estuaries and southwest coast (Fig. 1) it seems that a demographic increase (observed through comparing archaeological maps, e.g. Soares and Tavares da Silva, 2004) had developed immediately after the cold event. Some authors have been working on the impact of climate and environmental changes on Late Mesolithic and Early Neolithic communities (Berger, 2005; Berger and Guilaine, 2008), emphasizing the climatic and environmental factors in the emergence of the first agricultural societies. We prefer to focus on the dialectical rapport between environmental conditions and cultural adaptations (socio-environmental answers).

After $6200 \mathrm{cal} \mathrm{BC}$ (Table 1), when climatic amelioration was already in progress, in accordance with the results of the charcoal analysis of Vale Marim I (Queiroz and Mateus, 2016) (Table 2), no chronological or cultural gaps are observed until about 5000 cal BC
(Soares, 1995, 1997; Soares and Tavares da Silva, 2004). The beginning of the Early Neolithic (Vale Pincel I facies, with ceramic impressa affiliated in the pottery tradition of the west central Mediterranean basin) is currently radiocarbon dated at about 5700/5600 cal BC (Tavares da Silva and Soares, 2015), overlapping the end of the Late Mesolithic, as observed in Fiais and Vidigal (Table 1).

In the palaeo-estuaries of Tagus and Sado, Mesolithic hunter-fishergatherer communities persisted till a very late chronology, around 4700/4500 cal BC (Jackes and Alvim, 2006; Jackes and Meiklejohn, 2008; Soares, 2013, 2016), when estuarine conditions (saltwater influence and associated salt marsh species) migrated downstream (Jackes and Meiklejohn, 2008; Soares, 2013; Soares and Tavares da Silva, 2013; Freitas and Andrade, 2008), and the Neolithic economy was already disseminated all over the Portuguese territory. 


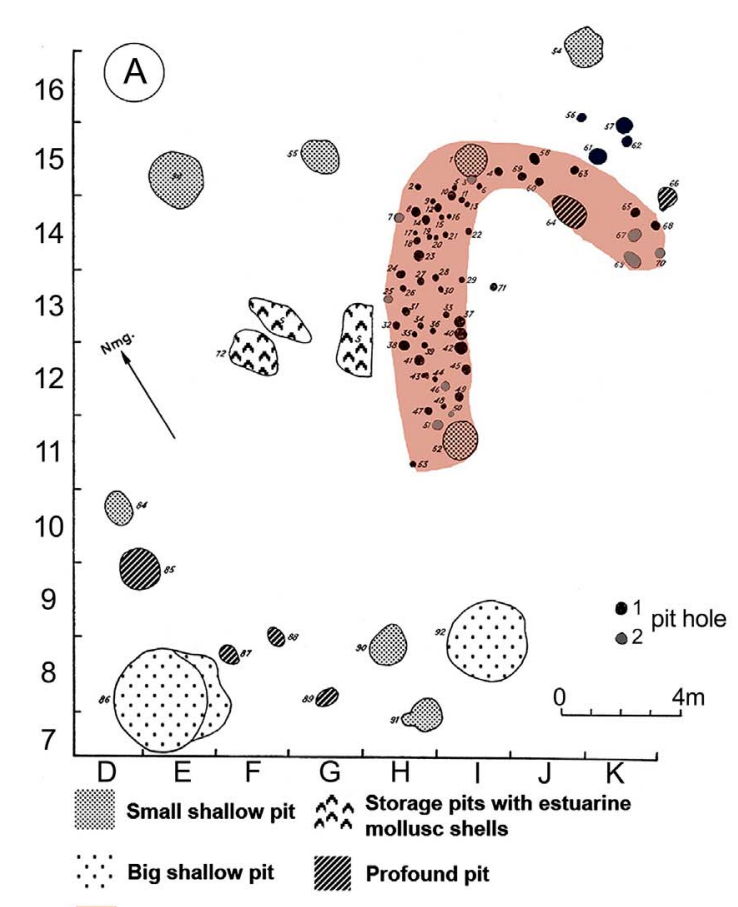

Limit of a probable hut in perishable materials

Adapted from: Roche, 1960 , fig. 25

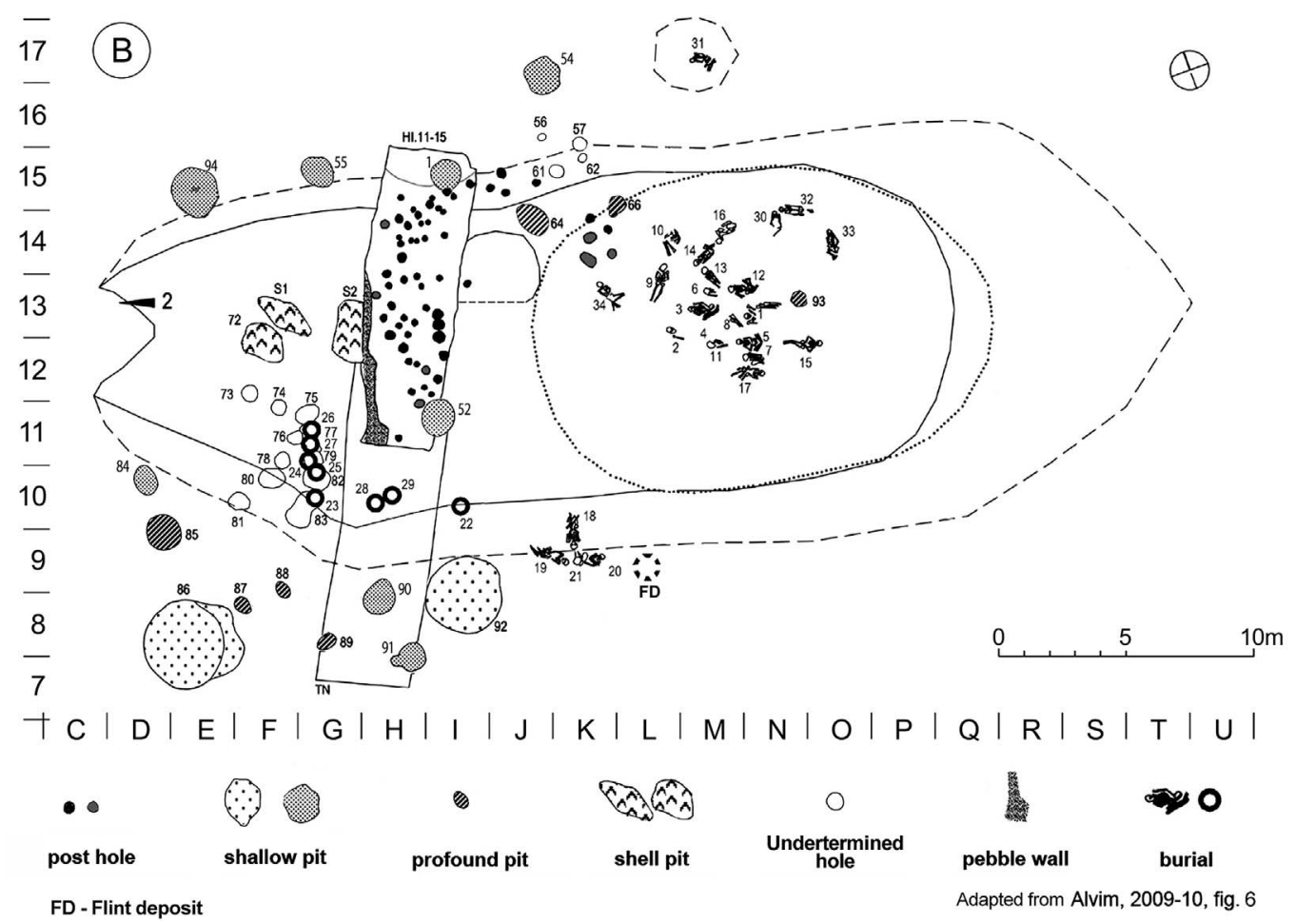

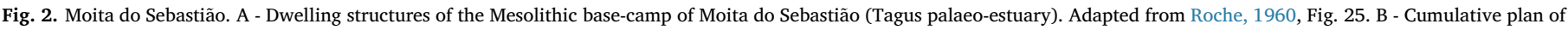
the lower Mesolithic layers of Moita do Sebastião excavated by Jean Roche. (After Alvim, 2009-2010).

\section{Regional settlement system: an overview}

On the southwest coast, the resources seasonality would schedule economic tasks that played an important role in dwelling acts and in the formation of the settlement system of the hunter-fisher-gatherer societies. There is evidence during the Late Mesolithic and Early Neolithic of a logistical mobility model (sensu Binford, 1980) with networks of base- camps and specialized short-term campsites (Fig. 1B) (Soares, 1995, 1996; Soares and Tavares da Silva, 2004; Soares, Tavares da Silva and Canilho, 2005-2007). In the base-camps a broad-spectrum subsistence strategy took place.

The Mesolithic broad-spectrum economy, based on a large diversity of food resources, big and small, high-ranked and low-ranked prey (Soares, 2013, Fig. 3, 2016), further enlarged by logistical exploitation 


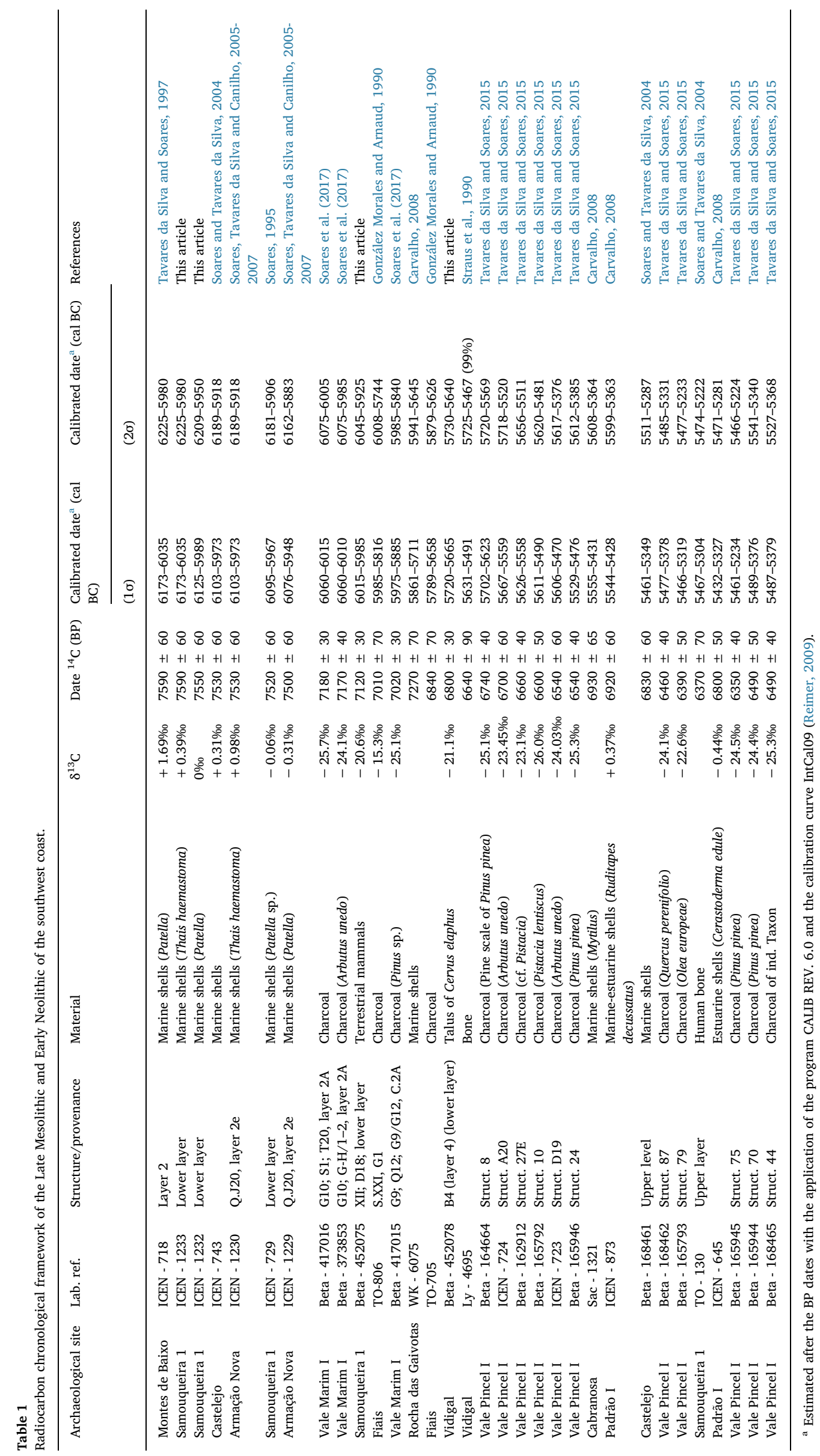


Table 2

Vale Marim I. Charcoal analysis by Paula Queiroz and José Mateus.

\begin{tabular}{|c|c|c|c|c|c|c|c|c|c|c|c|c|c|}
\hline Sample groups & $\begin{array}{l}\text { Pinus } \\
\text { pinea }\end{array}$ & $\begin{array}{l}\text { Pinus } \\
\text { pinaster }\end{array}$ & $\begin{array}{l}\text { Pinus } \\
\text { pinea/ } \\
\text { pinaster }\end{array}$ & $\begin{array}{l}\text { Pinus } \\
\text { sylvestris }\end{array}$ & $\begin{array}{l}\text { Olea } \\
\text { europaea }\end{array}$ & Populus & $\begin{array}{l}\text { Erica } \\
\text { umbellata }\end{array}$ & $\begin{array}{l}\text { Erica cf. } \\
\text { E. } \\
\text { arborea }\end{array}$ & $\begin{array}{l}\text { cf. Erica } \\
\text { arborea }\end{array}$ & cf. Erica & $\begin{array}{l}\text { Calluna } \\
\text { vulgaris }\end{array}$ & Undetermined & $\begin{array}{l}\text { Total } \\
\text { (number of } \\
\text { fragments) }\end{array}$ \\
\hline Sector F9 - c. 1b/2a1 & 7 & 2 & & & & & & & & & & & 9 \\
\hline Sector F9 - c. $2 a$ & 87 & 9 & 6 & & & & 1 & 1 & & & & 4 & 108 \\
\hline Sector F9 - c. $2 \mathrm{a} 2$ & 12 & 11 & 1 & 2 & & & & & & & & & 26 \\
\hline Sector F10 - c. $2 \mathrm{a} 1$ & 11 & 2 & 1 & & & & & & & & & & 14 \\
\hline Sector F10 - c. $2 \mathrm{a} 2$ & 22 & 2 & & & & & & & & & 1 & & 25 \\
\hline Sector G8 - c. $2 \mathrm{a} 2$ & 5 & 1 & & & & & & & & & & 1 & 7 \\
\hline Sector G9 - c. 2a & 71 & 12 & 13 & 1 & & 1 & & & 1 & 1 & & 3 & 103 \\
\hline Sector G9 - c. $2 b$ & 18 & & & & & & & & & & & & 18 \\
\hline Sector G10 - c. $2 \mathrm{a}$ & 33 & 2 & 1 & & & & 5 & & & & & 1 & 42 \\
\hline Sector G10 - c. 2a1 & 13 & 3 & & & & & & & & & & 3 & 19 \\
\hline Sector G10 - c. $2 \mathrm{a} 2$ & 23 & & & & & & & & & & & 2 & 25 \\
\hline Sector G10 - c. $2 \mathrm{a} 3$ & 6 & 1 & & & & & & & & & & & 7 \\
\hline Sector H9 - c. $2 a$ & 25 & 7 & & & & & & & & & & & 32 \\
\hline Sector H9 - c. $2 \mathrm{a} 1$ & 1 & & & & 4 & & & & & & & 1 & 6 \\
\hline Sector H10 - c. 2a & 12 & 1 & & & & & & & & & & 1 & 14 \\
\hline \multirow{2}{*}{$\begin{array}{l}\text { Total (morphological } \\
\text { type) }\end{array}$} & 346 & 53 & 22 & 3 & 4 & 1 & 6 & 1 & 1 & 1 & 1 & 16 & 455 \\
\hline & 76.04 & 11.65 & 4.84 & 0.66 & 0.88 & 0.22 & 1.32 & 0.22 & 0.22 & 0.22 & 0.22 & 3.52 & $100.00 \%$ \\
\hline
\end{tabular}

of the territory, would create a stable and reliable subsistence strategy. Progressively, the growing sedentarism and associated demographic increase would provoke an imbalance in the demographic/ecological interplay (Soares, 1992; Soares and Tavares da Silva, 2004; Davis and Detry, 2013). Although the demographic matter is not discussed in the present paper it seems that a possible fertility increase occurred at the Tagus Mesolithic, considering the ethnographic record of the current hunter-gatherer communities (Jackes and Meiklejohn, 2008, table 2).
During their reproductive period, the Mesolithic women of Muge would have during their reproductive period four to six children born in accordance with a total fertility pattern higher than the established in current hunter-gatherer societies (four live births).

Late Mesolithic hunter-gatherers would further intensify their economic base by means of storage, that could be applied to smoked fish and to low-risk storable food such as acorns of Quercus rotundifolia and pine nuts of Pinus pinea, available in autumn and winter

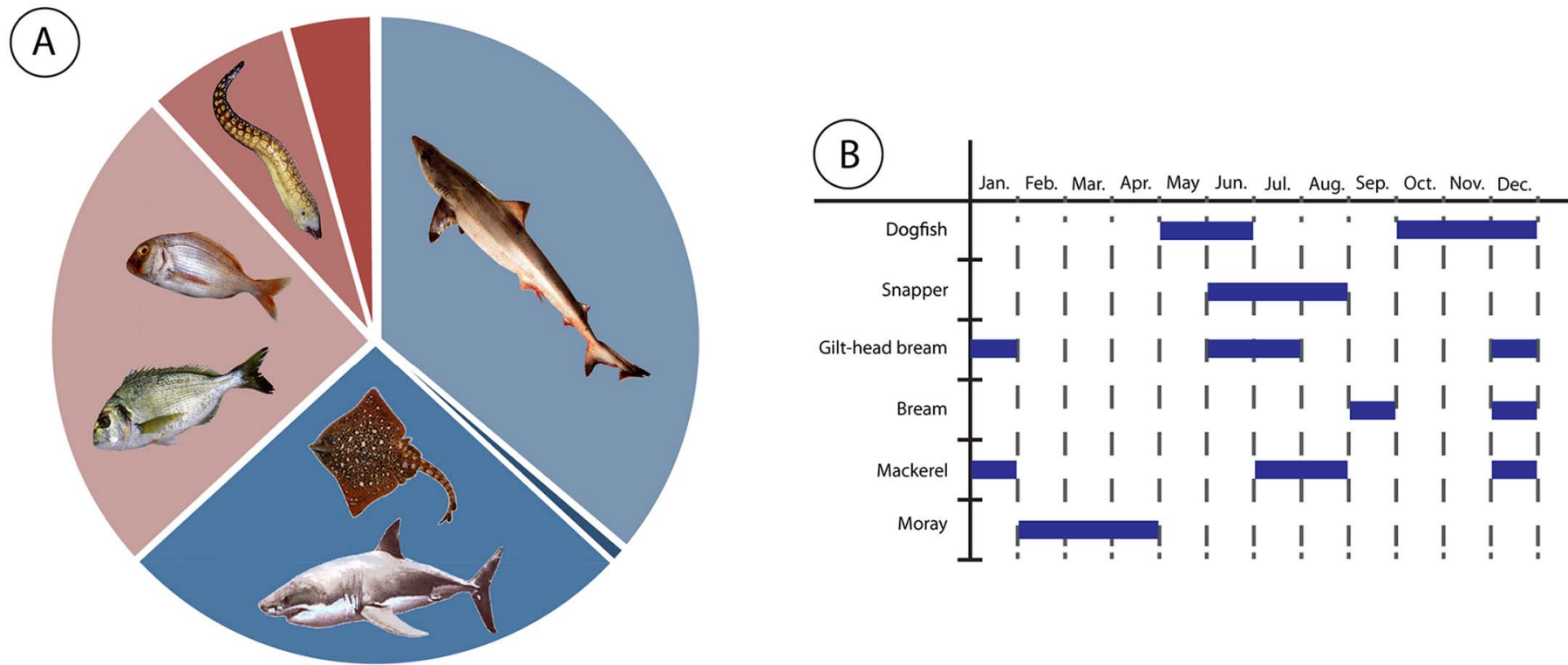

Chondrichthyes

Triakidae

(Dogfish) $(36,1 \%)$

Lamnidae and Sphyrnidae (Mako shark) $(0,9 \%)$

Chondrichthyes und.

$(26,3 \%)$

\section{Osteichthyes}

Sparidae (Gilt-head Muraenidae (Moray)

beam and othe

$(7,5 \%)$

species) (24,8\%,

Other fish species

from Serranidae,

Moronidae, Scianidae,

Scombridae, Mugilidae,

Pleuronectidae, Soleidae

$(4,5 \%)$

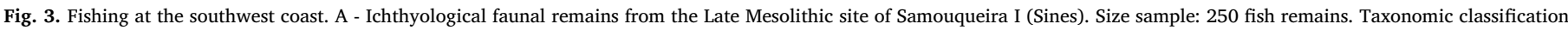
after Sónia Marques-Gabriel, 2015. B - Seasonality of the main fish species captured by the Late Mesolithic communities of the southwest coast. After Soares et al., 2017. 
(October-January). Thus, coastal Late Mesolithic groups would organize their foraging tactics and technology in association with a supposed increasing reliance on stored foods, with a focus on fish (Fig. 3), mainly dogfish, very resistant to biodegradation. Mesolithic communities were beginning to think on the advantages of the delayed return of human labour (Testart, 1982), which is a cognitive pre-condition for neolithization.

\subsection{Base-camps}

Large base-camps, located on ecotone zones nearby water sources, such as Vale Marim I, Samouqueira I, Vidigal and Fiais (Fig. 1B), were probably occupied all year round; they included functions of living and death, as observed at Fiais, Samouqueira I and Vidigal and also significant densities of artefacts. These sites were likely polynucleated as observed in the Late Mesolithic site of Vale Marim I.

Samouqueira I and Vale Marim I are located on the Atlantic outer coast, directly on the seashore cliffs composed of schist from the Carboniferous basement (Tavares da Silva and Soares, 1981), nowadays overhanging the ocean. But in the transition to Middle Holocene they were facing a large coastal plain approximately a kilometre wide, now submerged by the Flandrian transgression (Dias et al., 1997; Dias, 2004; Vanney and Mougenot, 1981). Vidigal is $2 \mathrm{~km}$ away from the ocean, on the left bank of the Queimado stream. Fiais is about $10 \mathrm{~km}$ away from the modern coastline, on the bank of a stream tributary of the Mira River, in the innermost sector of the Mira basin with tidal influence in the Mesolithic.

The sediments acidity and intense leaching had not allowed the preservation of organic remains at Vale Marim I (except for some charcoal fragments and molar teeth of Sparus aurata), but at the coeval sites of Samouqueira I, Vidigal and Fiais, fauna assemblages were preserved. All of them contained land mammals, fish and shellfish remains. At Samouqueira I (lower layer, 1984 field season), mammals were represented by Cervus elaphus, Sus scrofa, Bos primigenius, Lepus capensis, Vulpes vulpes, and Canis lupus familiaris(?) (Soares, 1995). Terrestrial mammals constitute about $8.7 \%$ by weight of a sample where fish remains comprise $1.3 \%$, and shellfish $90 \%$ (Soares, 1996). Mussels (Mytilus edulis) were the most abundant marine invertebrate species with $40 \%$, followed by whelks (Stramonita haemastoma) at $28 \%$, limpets (Patella sp.) at 26\%, and cockles (Cerastoderma edule) at $4 \%$, with a residual representation of Paracentrotus lividus and Pollicipes pollicipes (Soares, 1996, Table 3). The faunal remains obtained in the 1992 field season, from the same stratigraphic layer have not been published yet, except for the ichthyological taxa (Marques-Gabriel, 2015) (Fig. 3).

At Vidigal, more than $1 / 3$ of the total vertebrate faunal remains belong to ichthyologic species. Olivier LeGall et al. (1992, 1994) made a general classification, observing a dominance of small sharks and rays (Chondrichthyes class), most of them attributable to the Triakidae family (dogfish). There were also remains of a great variety of species from the Osteichthyes class, mainly gilthead bream (Sparus aurata). Land mammals are also well represented by Cervus elaphus, Bos primigenius, Sus scrofa, Oryctolagus cuniculus, Capreolous capreolous, Lynx pardinus and Felis sylvestris. Invertebrate fauna is dominated by Patella sp.; Stramonita haemastoma, Mytilus edulis and Ostrea sp.

The faunal record of Fiais included the same marine molluscs species present at Vidigal; there were also fish bones but hunting was the main activity. A very dense bone dump with several thousand land mammal specimens has been excavated: red deer (Cervus elaphus) at $70 \%$, wild boar (Sus scrofa ferus) at 14\%, roe deer (Capreolus capreolus) at 10\%, and auroch (Bos primigenius) at 6\% (González Morales and Arnaud, 1990; Rowley-Conwy, 2015).

Besides the diversity of the exploited food resources, these faunal assemblages highlight the practice of fishing in the outer coast sites, and the hunting, that would occur mainly in autumn and winter, from October to March (Soares, 2013; Rowley-Conwy, 2015), in the innermost locations like the estuarine/riverine site of Fiais, which can be interpreted as a result of some incipient system of goods exchange at the regional scale. Fishing, probably the main economic activity of the littoral Mesolithic groups with a reliance on dogfish, would be practiced probably at springtime, summer and early fall in accordance with the weather annual cycle, although some fish species would be available nearby the coast even in winter like moray (Fig. 3). Shellfish harvesting, scheduled at springtime and fall, is likely to have played an important role in all the considered sites.

\subsection{Short-term camps}

Small and seasonal multi-layered sites, such as Montes de Baixo (Tavares da Silva and Soares, 1997) and Castelejo (Soares and Tavares da Silva, 2004), presented shell-middens of huge captures of shellfish (no mammals, fish or bird remains). In those temporary campsites task groups returned recurrently to exploit seasonal resources probably to be brought back to the base-camps for consumption and/or storage. Those archaeological contexts have very low amounts of artefacts, mostly expediently manufactured on non-siliceous cobbles. At Armação Nova (Algarve), an embedded strategy of shellfish gathering and flint exploitation of the Lower Jurassic limestone from the São Vicente Cap outcrop was recognized (Soares, Tavares da Silva and Canilho, 20052007; Ribeiro and Terrinha, 2005-2007, 2007). The general scarcity of flint/chert on the southwest coast would make this raw material valuable enough to be stored at the base-camps; this behaviour was recognized at Vale Marim I. Some temporary camps (e.g. Montes de Baixo, Castelejo, Armação Nova) had been in use for long periods. Besides shellfish gathering they probably played other functional roles in the whole regional taskscape, namely as significant territorial markers of rare raw materials sources (e.g. Armação Nova) and paths where the groups signed their identity and ownership of the used territory in an extensive and experienced way.

\subsection{Taskscape and inhabitation process}

The proposed settlement pattern, in accordance with the available empirical record, is only a draft of a much more complex reality that requires further and more systematic research. If we perceive the concept of taskscape as landscape of action (Ingold, 1993, 2000; Robb, 2013; Driscoll, 2017) in order to understand the landscape construction of the Late Mesolithic communities such as dwelling and environment management, first we would have to analyse the way they deal with the sharp seasonal changes in our latitudes (the rhythmic motion of the seasons changing would constitute the cyclical backdrop to the groups everyday routines).

In the Middle Holocene, the Alentejo coast was covered by extensive post-glacial forests (Queiroz and Mateus, 2004) therefore the Mesolithic communities were woodland dwellers. As in Vale Marim I, they would locate their settlements in woodland glades (Queiroz and Mateus, 2016) caused by human intervention or by the natural cycle of the ecosystem. The way Mesolihtic communities managed forest and certainly particular trees for their economic benefit and other social purposes is very difficult to assess due to the general bad preservation conditions of organic materials in these particular archaeological contexts. In any case, at Vale Marim I, the forest was the main energetic source for domestic fire and also played important role in providing craft raw material (e.g. posts and stakes for huts, boats, etc.) and food resources, namely pine nuts of Pinus pinea.

Rivers, even small watercourses, were important corridors in the inhabitation process. Their estuaries were the preferred locations for Mesolithic habitat. Supposedly the ocean was not a boundary but a source of life with a strong position in the Mesolithic taskscape. This matter addresses to the crucial question of human-animal relations namely the particular relationship with fish in regard to the alleged central role of ocean and fishing at regional scale. The Lepenski Vir 
(Mithen, 1994) stone sculptures representing a hybrid identity half human half fish showed the complexity and the spirituality that some human-animal relations could reach, creating fluidity at the borders between humans and animals. Raising the issue of the dichotomic thinking between domesticated and wild (Hodder, 1990), it seems that the dog was also present at the southwest Late Mesolithic (Samouqueira I), as in Sado (Detry, 2002-2003) and in Tagus Mesolithic contexts (Detry and Cardoso, 2010).

\section{Vale Marim I. Environment and chronology}

Vale Marim I is a large open-air site (about 1 ha) in the municipality of Sines, on the south slope of the igneous hill of Chãos, facing S. Torpes bay (Tavares da Silva and Soares, 1981), currently over the ocean. Due to its high acidity and intense leaching, the sandy cultural layer, with only one occupational phase (layer 2A, Fig. 6), with about $10 \mathrm{~cm}$ in thickness, did not preserve organic materials with the exception of some charcoal fragments and gilthead molar teeth, which highlight the importance of fishing, as already stated.

The charcoal analysis by Queiroz and Mateus, 2016 revealed the existence of littoral pinewoods (Pinus pinea) in the surrounding area of the site (Table 2; Fig. 4). Pinus pinea is the predominant gathered species, well adapted to warm and dry atmospheric conditions, in sheltered spaces. In more exposed and windy areas there was Pinus pinaster; the residual presence of Pinus sylvestris contrasted with the extensive coverage of the Alentejo coast by this species during the Tardiglacial with cooling conditions. The archaeological layer had been dated by three radiocarbon determinations on charcoal samples (Beta-417016, $7180 \pm 30$; Beta-373853, $7170 \pm 40$; Beta-417015, $7020 \pm 30$ yrs. BP) that calibrated at 2 sigma given the time span of $6075-5840 \mathrm{cal} \mathrm{BC}$ (Table 1).

\subsection{Lithic industry}

The lithic assemblage of Vale Marim I is composed of 8900 artefacts, 7614 of which belong to the chipped curated technological subsystem mostly on flint/chert, 1249 were expediently manufactured on quartzite and greywacke cobbles, 31 are pecked and polished tools; there are also two schist beads and four raw material pieces. A random sample of 2078-flaked artefacts (1852 on flint/chert and 226 expediently manufactured on local cobbles) was submitted to a technological and typological study as well as 1213-curated artefacts on flint/chert, for usewear analysis (Soares et al., 2017). The analysed sample is quite representative of the variability of the curated technological subsystem; lithics were widely distributed all along the excavated area (Sectors F8, F9, G8, G9, G10, H9). The production of lithic artefacts was concentrated close to some hearths where cores and schist chisels were found (Fig. 5, $n^{\circ} 13-14$ ). The pre-heating of the raw material had been signalled at $2.9 \%$ in a sample of 343 artefacts that preserved signs of debitage techniques. Lithic blanks were produced on the site by reduction of non-local flint/chert cores; all the operational chain of production is represented despite the low overall cortical/non-cortical ratio, indicating an emphasis on the later stages of core-reduction and tool-production at the site. In a sample of 86 cores, only 28 have cortex remains.

The raw material provenance has not been completely studied, but nodular sources from S. Luis hill (acid siliceous-volcanic complex formation of Cercal) about $37 \mathrm{~km}$ south of the site, an 8 hour-walk (Oliveira, 1984) and from the Mesozoic basin of Santiago do Cacém (Deixa-o-Resto) at about $25 \mathrm{~km}$ further north (a 5 hour walk) had been recognized.

Flint/chert cores are mostly bladelet-cores. They are, in general, single-platform, with prismatic (conical) shape, reduced to a single face. Debitage products are mostly bladelets (average length: 23,3 mm:

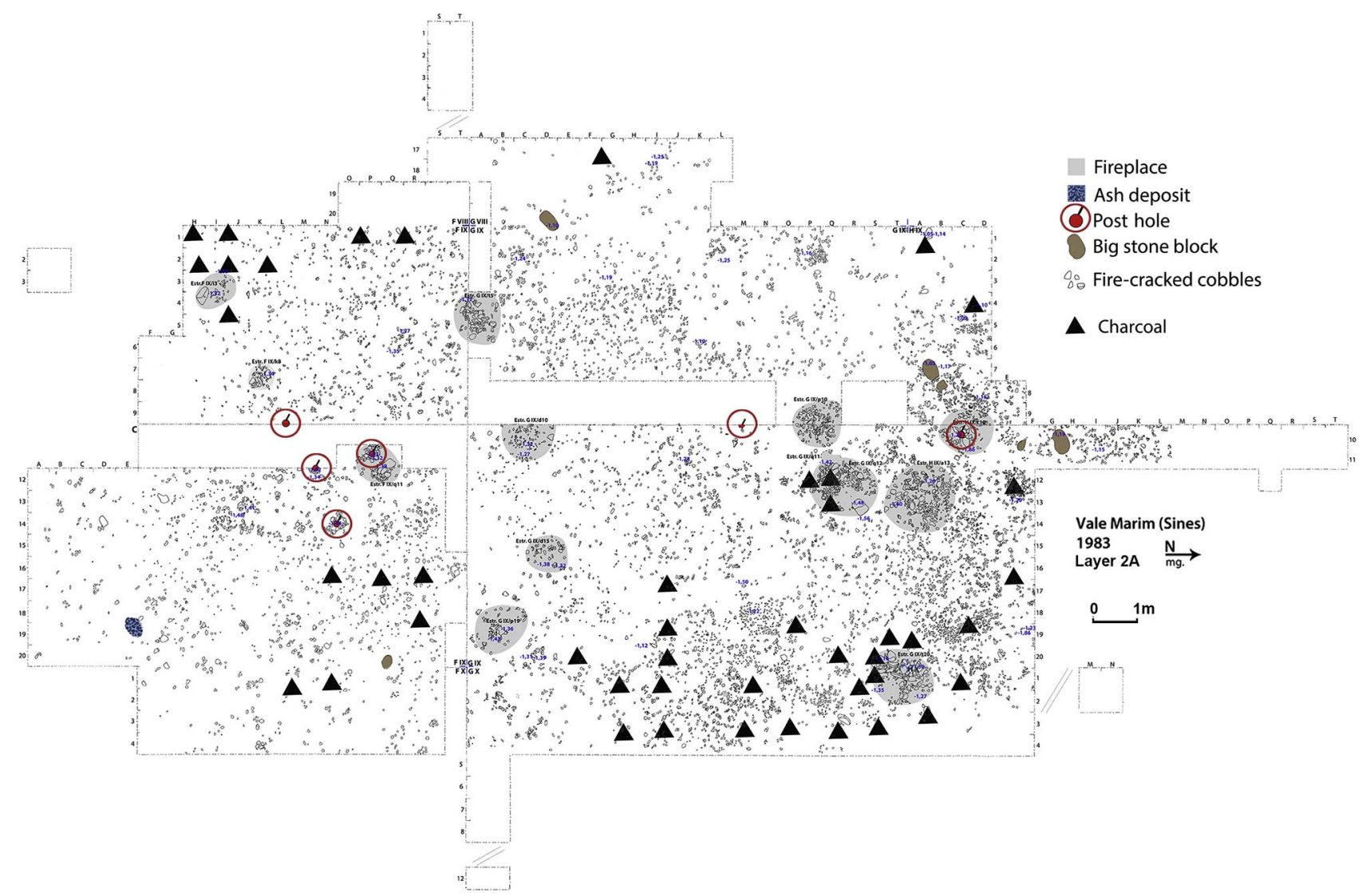

Fig. 4. Vale Marim I. Late Mesolithic archaeological layer (2A). Distribution of charcoal fragments mostly of Pinus (e.g. Table 2) 

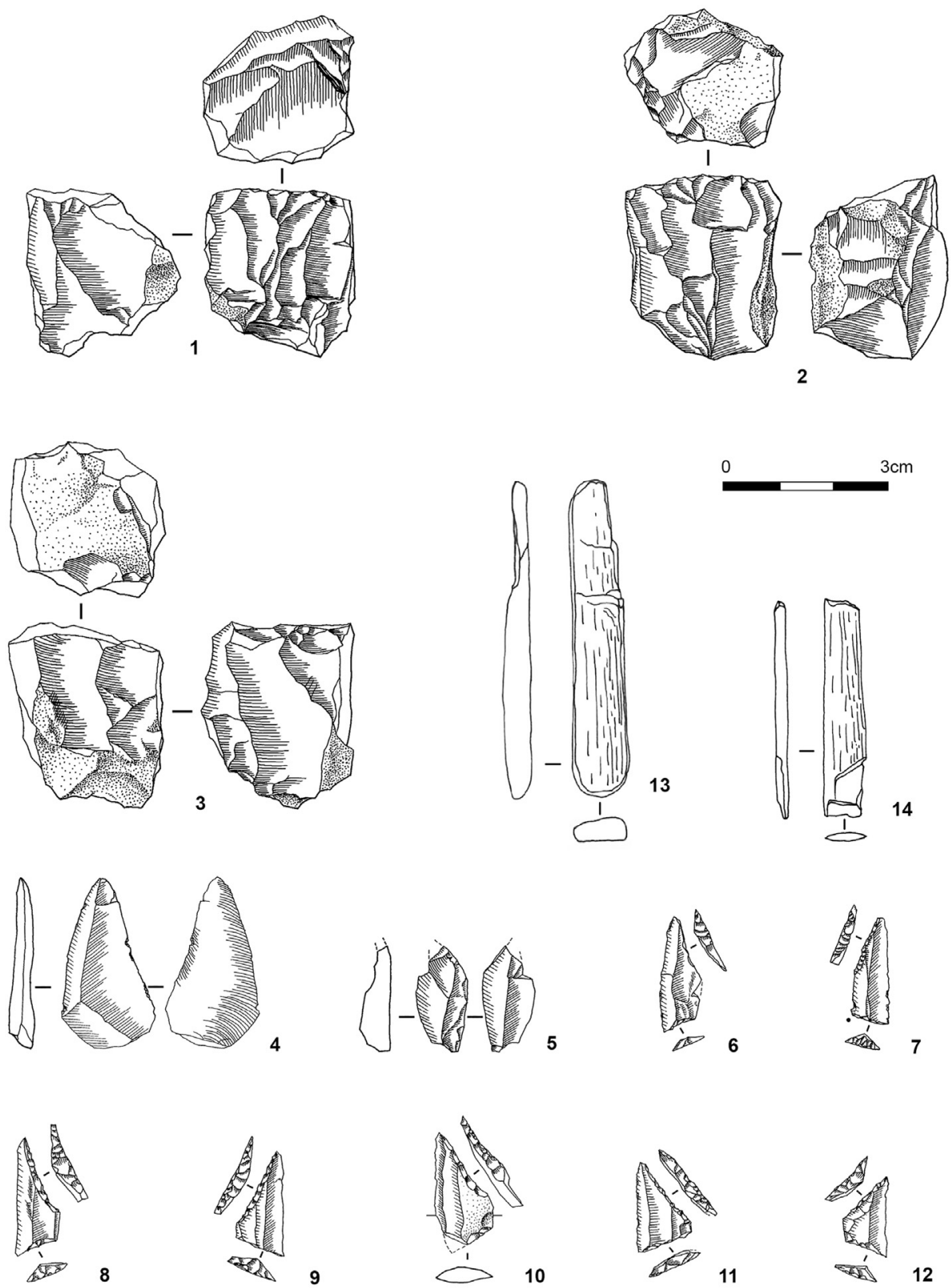

Fig. 5. Vale Marim I. Layer 2A. Lithic-curated industry on flint/chert, from the surroundings of hearth GIX/q12. 1-3flakes and bladelets cores; 4-5 - flakes with use-wear traces; 6-12 - Geometric tools (6-10) - asymmetric trapezes; 11-12 symmetric trapezes with the small base retouched - transition to the segment armature (?); 13-14 polished chisels on schist, probably used for indirect percussion associated to pre-heating technique.
0
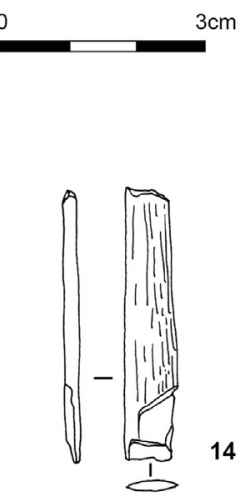

14

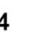

9
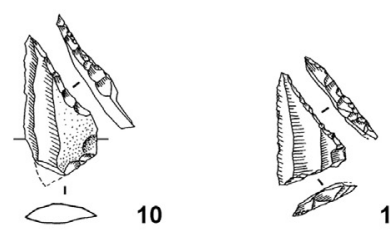
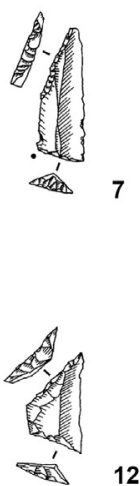

average width: 7,95 mm; average thickness: $2,46 \mathrm{~mm}$ ). Standardization in the process of blank tool production, that included decreasing variation in bladelet size/shape and increasing investment in core preparation, could be used as means of reducing costs of tool production and maintenance. All but two of the geometrics were made on bladelet blanks (average length: 17,49 mm: average width: $8,57 \mathrm{~mm}$; average thickness: 2, $38 \mathrm{~mm}$ ). Like other Late Mesolithic base-camps, Vale Marim I produced a geometric-based tool assemblage, dominated by trapezes ( $90 \%$ of the geometrics), using the microburin technique. The most common type is the asymmetrical trapeze (Fig. 5, n ${ }^{\circ}$ s. 6-10); there is also a trapeze type with a small base slightly retouched, which seems to make the transition to the segment shape that becomes dominant in the Early Neolithic (Fig. 5, n`s. 11-12).

The use-wear analysis (Soares et al., 2017) revealed 132 active zones, leaving a high percentage of unused blanks. At Vale Marim I, most of the detected use-wear traces were hardly developed. This means that lithic artefacts were often used for short working tasks.

There are 33 artefacts (20 flakes and 13 bladelets) with traces of functional management on hard materials: $\operatorname{wood}(\mathrm{N}=13,9.8 \%)$, bone
$(\mathrm{N}=9,6.8 \%)$, and undetermined $(\mathrm{N}=11,8.3 \%)$. Traces of working on animal and indeterminate soft materials have been also recognized, mostly on bladelets $(\mathrm{N}=46,34.8 \%)$, and on some flakes $(\mathrm{N}=12$, $14.4 \%)$. Besides traces of the processing of animal carcasses, there are use-wear traces very probably associated to fish processing (García and Clemente-Conte, 2011).

Traces of foraging activities are present on 33 geometric projectiles: in 19 cases, related to hunting and on 14 geometrics, probably due to the use of projectiles as harpoons for fishing.

\subsection{Lithic artefact spatial distribution and dwelling structures}

The taskscape concept is well suited to the chipped lithic industry. The first stage of decortication and roughing-out would have occurred mainly at the quarries (Soares et al., 2005-2007), but the preparation of core-platforms to the removal of debitage products is well expressed in Vale Marim I (Fig. 8B-C). The progress of the chaine operatoire with bladelet retouching edges, and geometric projectile points production through the microburin technique is also very well documented at Vale 


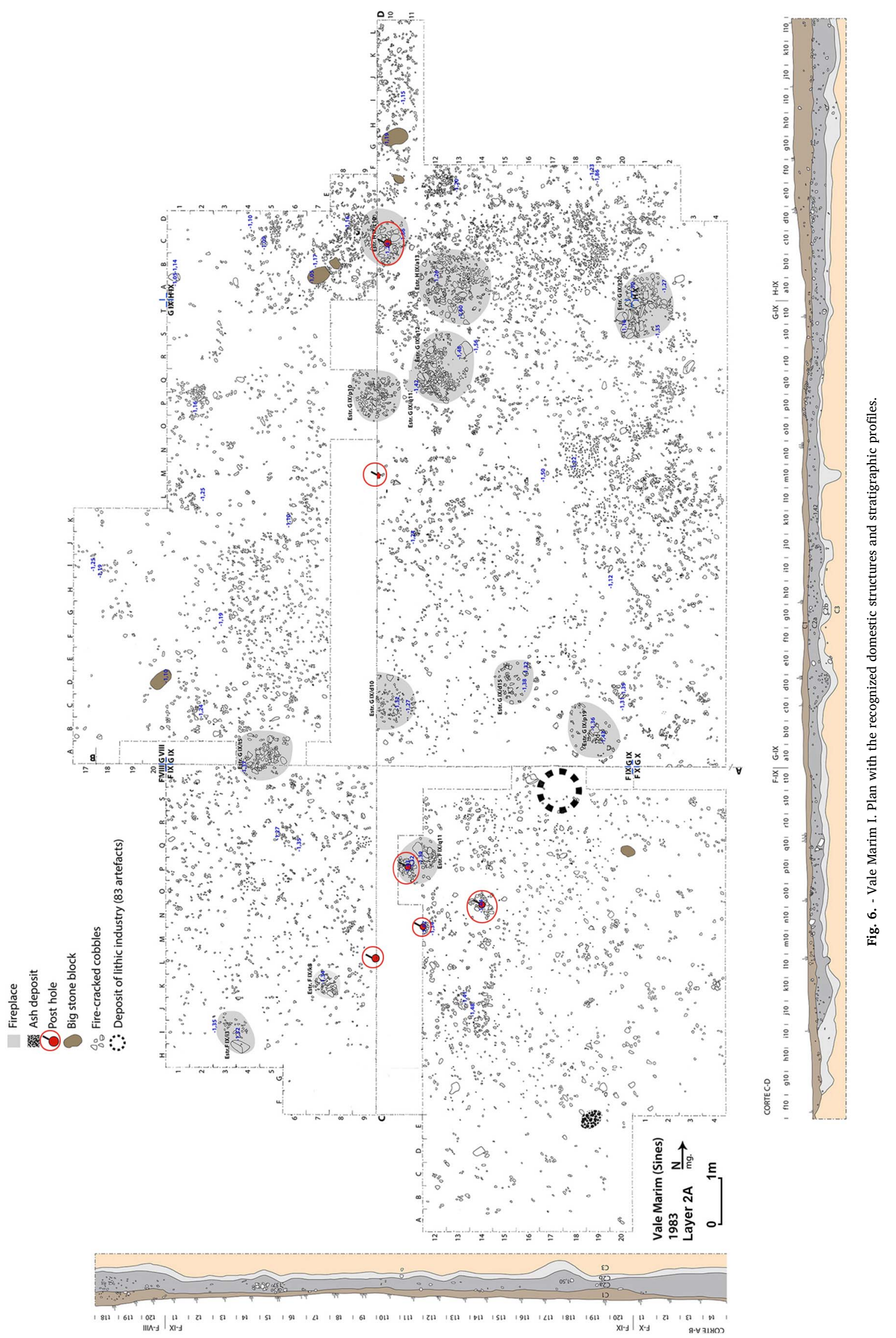




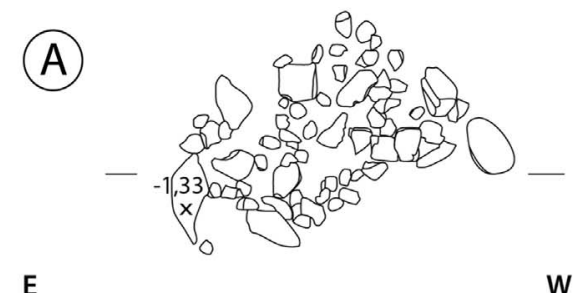

E
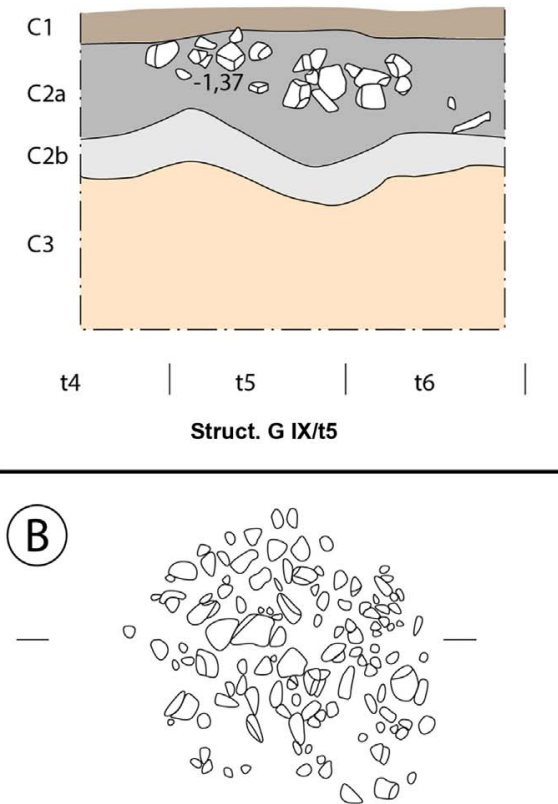

$\mathbf{S}$

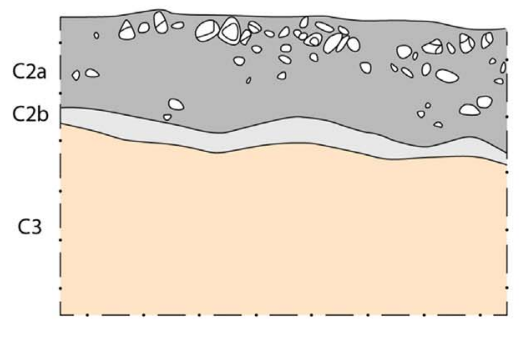

010

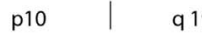

Struct. G IX/p10

Fig. 7. A-Hearths were installed generally in shallow pits filled with pebbles for heating conservation. B- In some cases they were installed at the surface covered by cobble pavement very adequate for grilling food. With use, pebbles got fire-cracked and the pavement progressively destroyed.

Marim I (Fig. 5). Maintenance routines and refitting works on the hunting implements and fishing gear took place in this probably logistical camp. Some hearths were specialized on lithic artefacts production, such as the GIX/q12 structure (Fig. 8A). Others, such as the FIX/q11 structure (Fig. 9A), could be destined to fish smoking (Fig. 9B-C). As the scarcity of organic materials is a strong limitation for social reconstruction, we have highlighted the spatial distribution of the lithic artefacts crossed with domestic structures, trying to find significant contexts to understand the dynamics of the living spaces of Vale Marim I (Fig. 10A-B).

The dwelling structures excavated at Vale Marim I (Figs. 6, 7, 8A, 9A) and Moita do Sebastião (Fig. 2) would probably polarize socioeconomic activities and constitute a framework through which we can get closer to the Late Mesolithic social organization. Those features are coherent with the idea of groups geared by incipient kinship relations, inside a hunter-fisher-gatherer-storage mode of production. In fact, the referred residential units would act as focus places for membership, for the affirmation of collective memory, cultural identity and intergenerational transfer of knowledge. The Mesolithic big hut of Moita do Sebastião (7-8 $\mathrm{m}$ in diameter) was largely opened to the exterior, and turned its entrance to southwards, sheltered against the northern winds (Roche, 1960). It was associated with a large amount of functionally diversified domestic structures (Fig. 2A), suggesting that this multifunctional area was the scenario for social acts.

Looking back at Vale Marim I, the main domestic energy source had been Pinus pinea wood (Table 2). The archaeological layer (2A) was covered by thousands of fire-cracked cobbles, by-products of hearth activity. Hearths are the most recognizable domestic structures, used probably for multipurpose functions such as heating, cooking, smoking fish, lithic industry manufacturing, other crafts and social interaction. They were installed generally in shallow pits filled with pebbles to conserve the heat (Fig. 7A) or covered with cobble pavements very adequate for grilling food (Fig. 7B); with the use, pebbles got firecracked, and the pavements were progressively destroyed.

There is a particular hearth (Fig. 8A), already mentioned, provided with a stone seat, likely destined to knapping activity. Around it there were polished chisels, used for indirect percussion technique, a concentration of flint cores and other artefacts like geometrics (Fig. 5). The presence of the pre-heating raw material technique observed on the artefacts fits well with the spatial core distribution pattern concentrated close to some hearths like structure FIX/i3 and GIX/q12 (Fig. 8B-C).

As the base of the site was composed of sand, post holes were found in very particular situations, where the pit had been fully filled with ash (GIX/m10), or where the post hole was limited by stones. This is the case in structure FIX/q11 where it had been possible to register a hearth and a stoned post hole in connection (Fig. 9A). This structure contained remains of Sparus aurata. Thus, we interpreted that hearth as a specialized structure dedicated to the fish smoking activity (Fig. 9B). In general, post holes have small diameters (mostly with 13-15 cm; one case with about $30 \mathrm{~cm}$ ) and are spatially connected with hearths. For fish grilling the most adequate fireplaces were covered by cobble pavements (Fig. 7B). We observed this procedure in the fisher community of Cadeireiros at Vale Figueira beach (Sines coast), in the 1970-decade of the 20th century. Only two post holes could be related with huts; they are dissociated from fireplaces in an area with latent remains of probable huts (sector FIX/square 19; sector GIX/square m10).

The spatial distribution of domestic structures and lithic artefacts (Figs. 6-10) allowed the delimitation of a minimum of three activity areas - AA I-III - (Fig. 10B) that surpassed the excavated surface; although the southern limit of the archaeological excavation is coincident with the south border of this habitat nucleus, as it can be observed in the profiles C-D (Fig. 6), which suggests that over the 1 ha of the archaeological site the occupation was not continuous but may be organized into several nucleus, having not necessarily been in simultaneous use. Thus, the excavated nucleus would have a minimum of about $300 \mathrm{~m}^{2}$ and a minimum of three main activity areas (Fig. 10B) separated by spaces almost empty of material culture and domestic structures, where huts, in perishable materials, could be located.

In front of the entrance of the probable huts there were hearths and high concentrations of artefacts documenting intense social and craft activity (AA I and II, Fig. 10A-B); the scarcity of artefacts and recognizable structures in the intermediate space between the activity areas are interpreted as latent remains of probable huts. The activity area III (Fig. 10B) is very different from the others. Lithic artefact density is very low, with the exception of an abnormal concentration (Sector F10; Square R-S/17-18), namely with microlithic geometric armatures (trapezes) of projectiles, indicating a probable storage structure. There is a concentration of hearths; some of them associated with post holes possibly used for smoking fish (i.e. structure FIX/q11, Fig. 9A-B). So we can propose for this area probable functions of fish smoking and storage of flint/chert artefacts. 

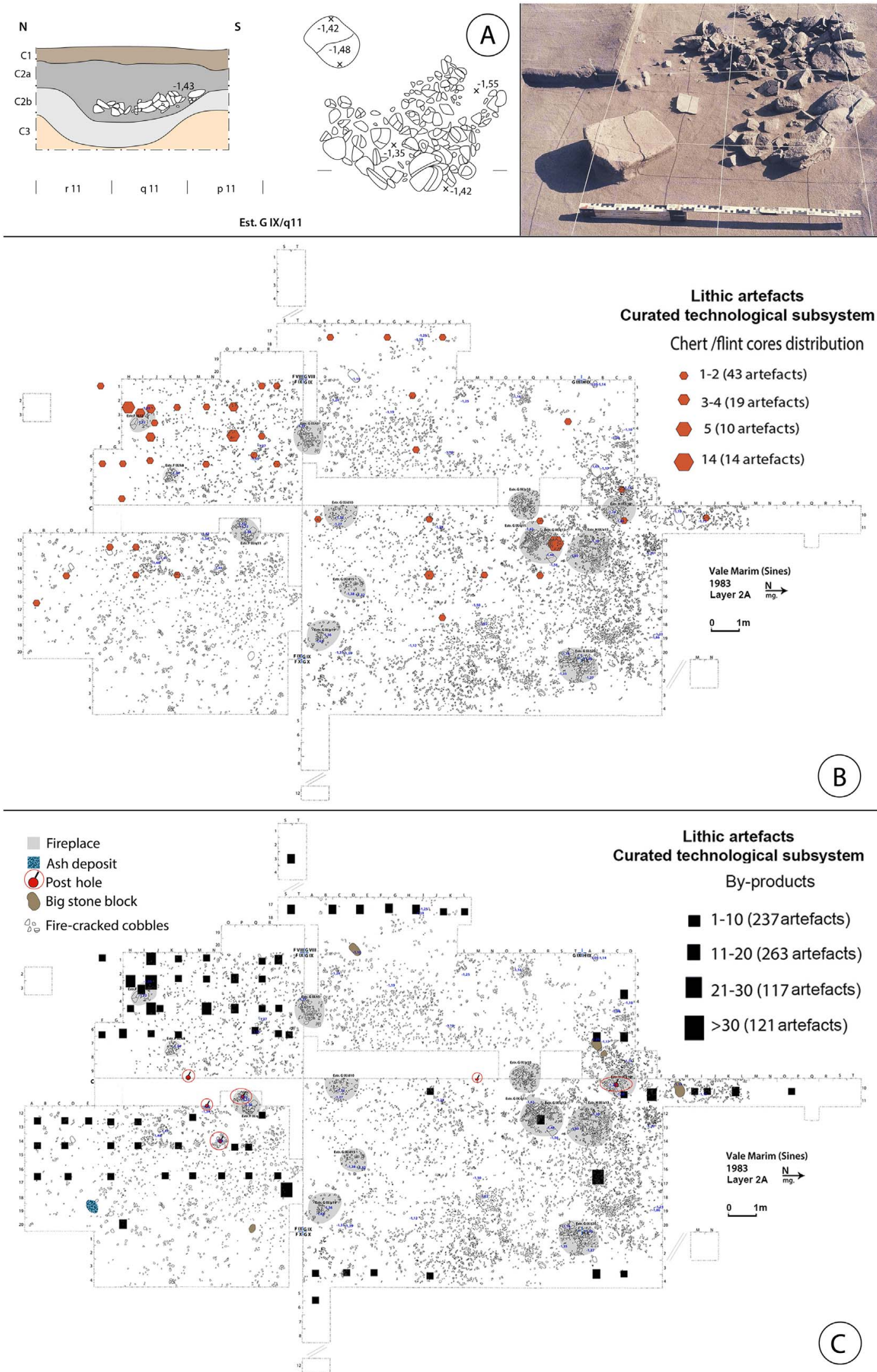

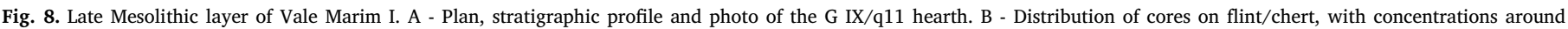
fireplaces, namely the G IX/q12 hearth. C - Distribution of the by-products of the lithic tools manufacture. 


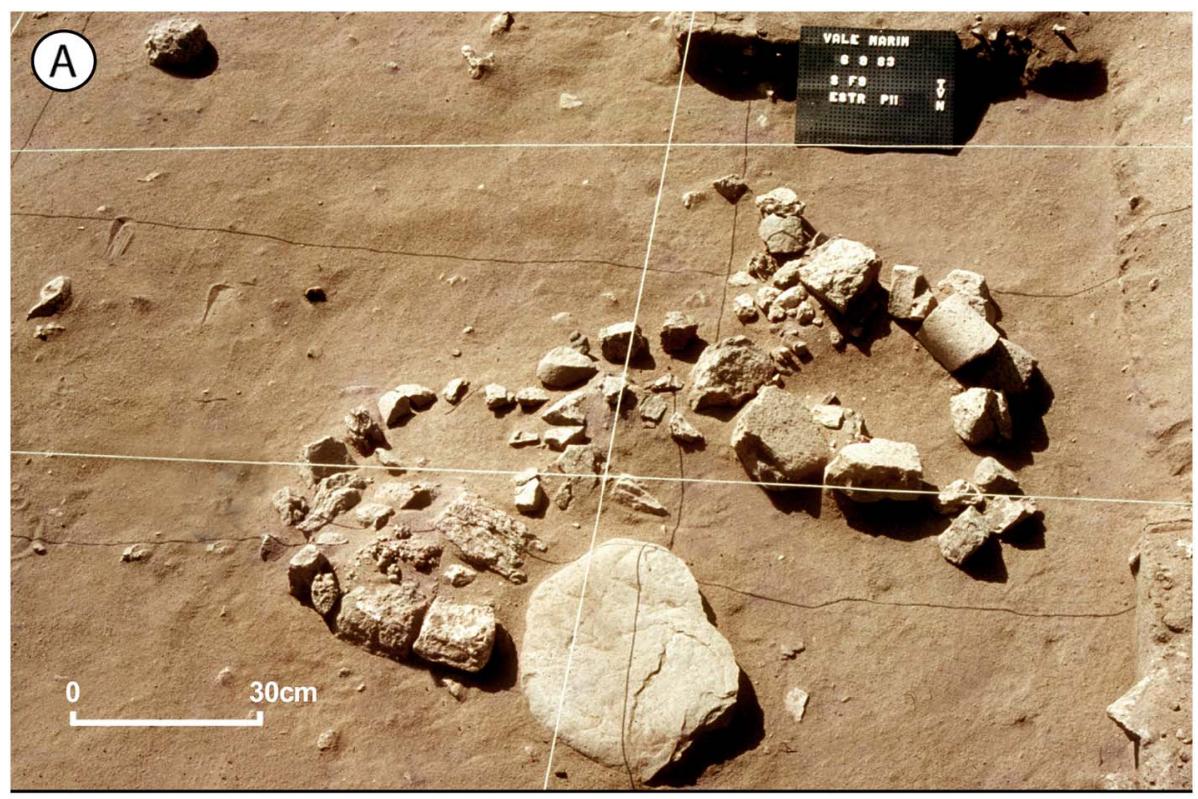

Fig. 9. A-The domestic structure FIX/q11 contained Sparus aurata molar teeth and was composed by a fireplace with fire-cracked cobbles packed into sandy-grey sediment with ash traces (first plan) linked to a stoned post hole (second plan). B - Reconstitution of a smoking fish scene inspired in Gasco, 1983. C - Although the unfavourable conditions of organic materials preservation, some teeth of gilthead bream were recovered as a direct evidence of the importance of fishing; they were located in the areas of major human activity.
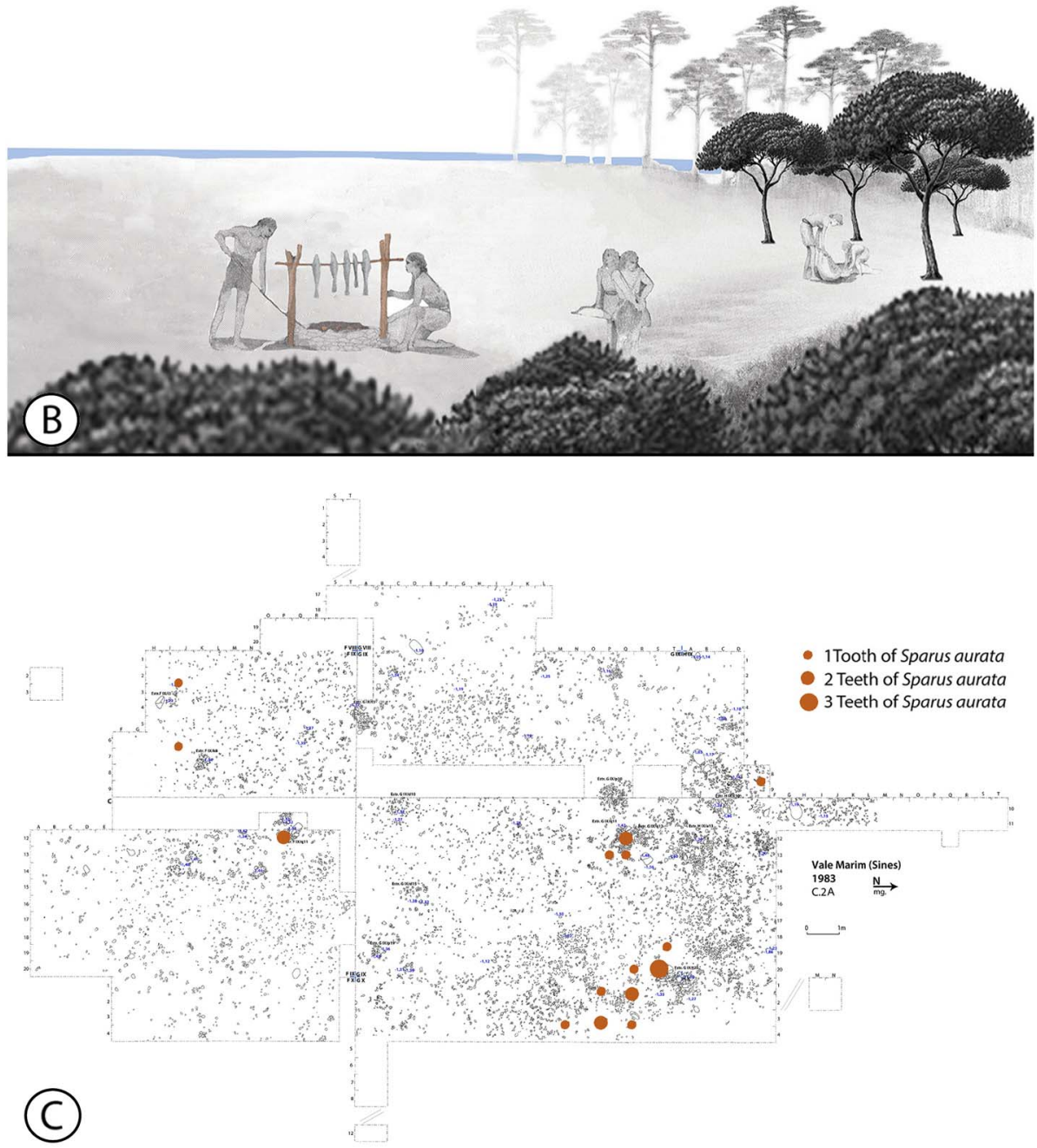

\section{Conclusion}

By looking at the dwelling evidence from Vale Marim I, namely fireplaces, and although at a first glance they seem to have a chaotic dispersal, they obey to a spatial organization to which we tried to get access through the spatial distribution patterns of the lithic artefacts. Taking into account the archaeological information from Moita do Sebastião (Roche, 1960), from the ethnoarchaeological approach developed at Pincevent (Leroi-Gourhan and Brézillon, 1972), and from anthropological studies of current hunter societies (Binford, 1983; 

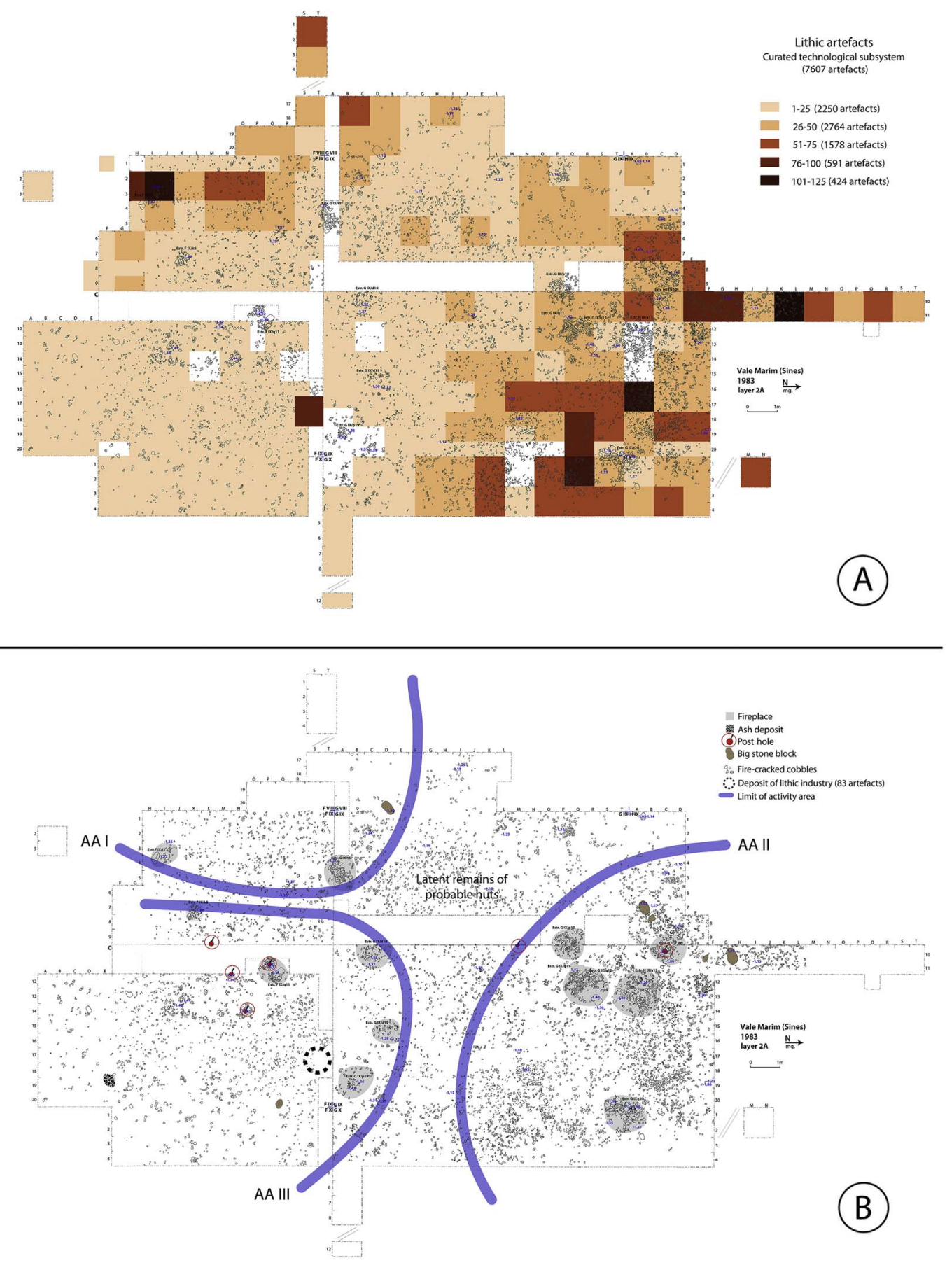

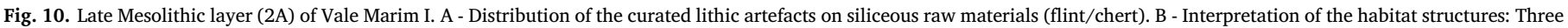
main areas of activity.

Grøn, 2015), we propose for the Late Mesolithic habitat of Vale Marim I a polinucleated spatial organization. Inside each nucleus, the living space was polarized by open-air activity areas with concentrations of hearths that would be places of intense and diverse social purposes. Behind them, would be the large entrances of flimsy huts whose latent remains (sensu Leroi-Gourhan and Brézillon, 1972) were constituted by spaces between activity areas, empty of domestic structures and with very small amounts of material culture. They were certainly made of organic materials, constructed in a very light way, opened mostly to south and east.

The overlapping functions of life and death that characterizes the Late Mesolithic base-camps could not be confirmed or denied at Vale Marim I for taphonomic reasons. Theoretically, we can admit a strong possibility of their occurrence, responsible for creating enduring places of memory, where ancestor's rituals could feed collective identities and lineage emergence. The material and immaterial contents of these places would be the hallmark of the regional cultural identity, the recognizable source of some incipient membership system and the symbol of bounded social units. The high degree of linkage and overlapping between huts, graves, and workshop areas show the persistent motion of communities towards increasing social stability. This is one of the major indicators of Mesolithic progression in the pathway to neolithization, a process that began well before the adoption of domestic species. Although dwelling remains are very fragmented and even latent at Vale Marim I and Moita do Sebastião they fit well with the idea of a semi-sedentary settlement pattern and with the emergence of an 
incipient kinship structure supported by a forager economy with storage in the Late Mesolithic of southern Portugal.

\section{Acknowledgements}

We would like to thank Susana Duarte, Teresa Rita Pereira, Fernanda Fino and António Júlio Costa from the Archaeological Studies Centre of MAEDS for their contribution to the preparation of the data from Vale Marim I. Our thanks also go to Barbara Polyak for the translation of the first version of this paper and to Maria José Pereira for the English proofreading. Finally, an acknowledgement is due to the reviewers, whose comments gave me the opportunity to explain aspects of the text that were less explicit.

\section{References}

Alley, R.B., Agustsdottir, A.M., 2005. The 8.2k event: cause and consequences of a major Holocene abrupt climate change. Quat. Sci. Rev. 24, 1123-1149.

Alvim, P., 2009-2010. Moita do Sebastião, 1952-54: o núcleo de um concheiro de Muge. 7-8. Promontoria, pp. 7-20.

Barradas, L.A., 1936. Concheiros do vale do Sado. 21. Anais da Faculdade de Ciências do Porto, pp. 175-179.

Berger, J.-F., 2005. Sediments, dynamique du peuplement et climat au Neolithique ancient. In: Guilaine, J. (Ed.), Populations neolithiques et environnements. Errance, Paris, pp. 155-212.

Berger, J.-F., Guilaine, J., 2008. The 8200 cal BP abrupt environmental change and the Neolithic transition: a Mediterranean perspective. Quat. Int. 200 (1-2), 31-49. http://dx.doi.org/10.1016/j.quaint.2008.05.013.

Bicho, N., Umbelino, C., Detry, C., Pereira, T., 2010. The emergence of Muge Mesolithic shell middens in Central Portugal and the 8200 cal yr BP cold event. J. Isl. Coast. Archaeol. 5 (1), 86-104.

Binford, L.R., 1980. Willow smoke and dogs' tails: hunter-gatherer settlement systems and archaeological site formation. Am. Antiq. 45, 4-20.

Binford, L.R., 1983. Working at Archaeology. Academic Press, London.

Cardoso, J.L., 2007. Pré-história de Portugal. Universidade Aberta, Lisboa.

Carvalho, A.F., 2008. A neolitização do Portugal meridional. Os exemplos do Maciço Calcário Estremenho e do Algarve Ocidental (Ph.D. Dissertation). Universidade do Algarve, Faro.

Costa, F.A.P., 1865. Da existência do homem em epochas remotas no valle do Tejo. Comissão Geológica de Portugal/Imprensa Nacional, Lisboa.

Costa, A.M., Freitas, M.C., Arias, P., Diniz, M., Araújo, A.C., Andrade, C., Rodrigues, A., Duarte, J., Cachão, M., Leira, M., 2015. Lower Sado basin sediments: a source for information for the late Mesolithic behaviour. In: Proceeding of Progress in Quaternary Archive Studies in the Iberian Peninsula, Seville, March 2015.

Davis, S., Detry, C., 2013. Crise no Mesolítico: evidências zooarqueológicas. In: Arnaud, J., Martins, A., Neves, C. (Eds.), Arqueologia em Portugal. 150 Anos. Associação dos Arqueólogos Portugueses, Lisboa, pp. 297-309.

Detry, C., 2002-2003. Estudo Arqueozoológico de um concheiro mesolítico do Sado Cabeço do Pez (Alcácer do Sal, Portugal) (Trabalho de introdução à investigação histórico-arqueológica). Universidade de Salamanca.

Detry, C., Cardoso, J.L., 2010. On some remains of dog (Canis familiaris) from the Mesolithic shell-middens of Muge, Portugal. J. Archaeol. Sci. 37 (11), 2762-2774. http://www.sciencedirect.com/science/article/pii/S0305440310001974.

Dias, J.M.A., 2004. A história da evolução do litoral português nos últimos vinte milénios. In: Tavares, A.A., Tavares, M.J.F., Cardoso, J.L. (Eds.), Evolução geohistórica do litoral português e fenómenos correlatives. Universidade Aberta, Lisboa, pp. 156-170.

Dias, J.A., Rodrigues, A., Magalhães, F., 1997. A evolução da linha da costa, desde 0 último máximo glaciário até à actualidade: síntese dos conhecimentos. Estudos do Quaternário I. pp. 53-66.

Diniz, M., Arias, P., Araújo, A.C., Armendariz, A., Teyra, L., Simões, C., Costa, A., 2016. O Mesolítico do vale do Sado e o projecto Sado-Meso-2010-2016: novos dados de terreno. Paper presented at the IX Encontro de Arqueologia do Sudoeste da Península Ibérica, Tróia, November 4th 2016. (in press).

Driscoll, K., 2017. Approaching the Mesolithic through taskscapes: a case study from western Ireland. In: Rajala, U., Mills, P. (Eds.), Forms of Dwelling 20 Years of Taskscapes in Archaeology. Oxbow-books, Oxford, pp. 41-61.

Freitas, M.C., Andrade, C., 2008. O estuário do Sado. In: Soares, J. (Ed.), Embarcações tradicionais. Contexto físico-cultural do estuário do Sado. MAEDS/APSS, Setúbal, pp. 21-29.

García, V., Clemente-Conte, I., 2011. Procesando pescado: reproducción de las huellas de uso en cuchillos de sílex atribuibles al trabajo de pescado. In: Morgado, A., Baena, J., García, D. (Eds.), La investigación experimental aplicada a la arqueología. Universidad de Granada, Granada, pp. 163-169.

Gasco, J., 1983. Premières paysans de la France méditerranéenne. Direction du Patrimoine/Office départementel d'action culturel del Hérault, Paris.

González Morales, M.R., Arnaud, J., 1990. Recent research on the Mesolithic in the Iberian Peninsula: problems and perspectives. In: Vermeersch, P., Van Peer, P. (Eds.), Contributions to the Mesolithic in Europe. Leuven University Press, Leuven, pp. 451-461.

Grøn, O., 2015. Territorial infrastructure, markers and tension in Late Mesolithic HunterGatherer Societies: an ethnoarchaeological approach. In: Bicho, N., Detry, C., Price,
T.D., Cunha, E. (Eds.), Muge 150th: The 150th Anniversary of the Discovery of Mesolithic Shellmiddens. vol. 2. Cambridge Scholars Publishing, Cambridge, pp. 253-269.

Hodder, I., 1990. The Domestication of Europe. Blackwell, Oxford.

Ingold, T., 1993. The temporality of the landscape. World Archaeol. 25 (2), 152-157.

Ingold, T., 2000. The Perception of the Environment: Essays in Livelihood, Dwelling and Skill. Routledge.

Jackes, M., Alvim, P., 2006. Reconstructing Moita do Sebastião, the first step. In: Bicho, N., Veríssimo, N.H. (Eds.), Do Epipapelolítico ao Calcolítico na Península Ibérica. Actas do IV Congresso de Arqueologia Peninsular (Faro, 2004). Universidade do Algarve, Faro, pp. 13-25.

Jackes, M., Meiklejohn, C., 2008. The paleodemography of central Portugal and the Mesolithic-Neolithic transition. In: Bocquet-Appel, J.P. (Ed.), Recent Advances in Paleodemography: Data, Techniques, Patterns. Springer, Netherlands, pp. 209-258.

LeGall, O., Straus, L.G., Vierra, B., Altuna, J., 1992. Ichtyofaunas and seasonality at Vidigal (Alentejo, Portugal). Mesolithic Miscellany 13 (2), 13-18.

LeGall, O., Altuna, J., Straus, L.G., 1994. Les faunes mésolithique et néolithique de Vidigal (Alentejo, Portugal). Archaeozoologia VII (1). pp. 59-72.

Leroi-Gourhan, A., Brézillon, M., 1972. Fouilles de Pincevent. Essai d'analyse ethnographic d'un habitat magdalénien (la section 36) (VIIe supplément à Gallia Pré-histoire). CNRS, Paris.

Marques-Gabriel, S., 2015. La ictiofauna del Holoceno Inicial y Médio de Portugal. Facultad de Ciencias, Universidad Autónoma de Madrid (Unpublished PhD thesis).

Martins, J.M.M., Carvalho, A.F., Soares, A.M.M., 2008. A calibração das datas de radiocarbono dos esqueletos humanos de Muge. 6(6). Promontoria, pp. 73-93.

Mithen, S., 1994. The Mesolithic Age. In: Cunliffe, B. (Ed.), The Oxford Illustrated History of Prehistoric Europe. Oxford University Press, Oxford, pp. 79-135.

Oliveira, J., 1984. Carta Geológica de Portugal: Notícia Explicativa da Folha 7. Serviços Geológicos de Portugal, Lisboa.

Queiroz, P.F., Mateus, J.E., 2004. Paleoecologia Litoral entre Lisboa e Sines. Do Tardiglaciário aos tempos de hoje. In: Tavares, A.A., Tavares, M.J.F., Cardoso, J.L. (Eds.), Evolução Geohistórica do Litoral Português e Fenómenos Correlativos. Geologia, História, Arqueologia e Climatologia. Universidade Aberta, Lisboa, pp. 257-304.

Queiroz, P.F., Mateus, J.E., 2016. Estudo arqueobotânico do povoado mesolítico de Vale Marim I (Sines). (unpublished report).

Reimer, P.J., 2009. IntCal09 terrestrial radiocarbon age calibration, 0-26 cal Kyr BP. Radiocarbon 51, 1111-1150.

Ribeiro, C., 1884. Les Kjoekkenmoedings de la vallée du Tage. In: Compte-rendu IX ème session. Congrés International d'Anthropologie et Archéologie Préhistorique (Lisboa, 1880). Lisbon, pp. 279-290.

Ribeiro, C., Terrinha, P., 2005-2007. Ocorrências de sílex na zona ocidental da bacia algarvia (Sagres). In: Soares, J., Tavares da Silva, C., Canilho, M.H. (Eds.), Matériasprimas minerais e mobilidade logística no Mesolítico da Costa Sudoeste. Os sítios de Samouqueira I e Armação Nova. Musa. Museus, Arqueologia e Outros Patrimónios. 2. pp. 63-66.

Ribeiro, C., Terrinha, P., 2007. Formation, deformation and certification of systematic clastic dykes in a differentially lithified carbonate multilayer. SW Iberia, Algarve Basin, Lower Jurassic. Sediment. Geol. 196, 201-215.

Robb, J., 2013. Material culture, landscapes of action, and emergent causation. Curr. Anthropol. 54, 657-683.

Roche, J., 1960. Le gisement Mésolithique de Moita do Sebastião (Muge, Portugal). I-Archéologie. Instituto de Alta Cultura, Lisboa.

Rowley-Conwy, P., 2015. The Late Mesolithic of Southwest Portugal: a zooarchaeological approach to resource exploitation and settlement patterns. In: Bicho, N., Detry, C., Price, T.-D., Cunha, E. (Eds.), The 150th Anniversary of the Discovery of Mesolithic Shellmiddens. vol. 1. Cambridge Scholars, Newcastle upon Tyne, pp. 255-272.

Soares, J., 1992. Les territorialités produites sur le littoral Centre-Sud du Portugal au cours du processus de néolithisation. Setúbal Arqueológica. 9-10. pp. 19-35.

Soares, J., 1995. Mesolítico-Neolítico na Costa Sudoeste: transformações e permanências. Trabalhos de Antropologia e Etnologia (Actas do $1^{\circ}$ Congresso de Arqueologia Peninsular, VI). 35(2). pp. 27-45.

Soares, J., 1996. Padrões de povoamento e subsistência no Mesolítico da Costa Sudoeste portuguesa. Zephyrus. 49. pp. 109-124.

Soares, J., 1997. A transição para as formações sociais neolíticas na Costa Sudoeste portuguesa. In: Rodríguez Casal, A. (Ed.), O Neolítico Atlântico e as Orixes do Megalitismo (Actas do Colóquio Internacional). Consello da Cultura Galega/ Universidad de Santiago de Compostela/Unión Internacional das Ciências Prehistóricas e Protohistóricas, Santiago de Compotela, pp. 587-608.

Soares, J., 2013. Caçadores-recolectores semi-sedentários do Mesolítico do paleoestuário do Sado (Portugal). In: Soares, J. (Ed.), Pré-História das Zonas Húmidas/Prehistory of Wetlands (Setúbal Arqueológica, 14). MAEDS-ADS/SIMARSUL, S.A, Setúbal, pp. $13-56$.

Soares, J., 2016. Rethinking the Mesolithic of the Sado Paleoestuary, Portugal: semi-sedentary Hunter-gatherers. In: Bjerk, H., Breivik, H., Fretheim, S., Piana, E., Tivoli, A., Zangrando, A., Skar, B. (Eds.), Marine Ventures - Archaeological Perspectives on Human-Sea Relations. Equinox Publishings, Sheffield, pp. 241-260.

Soares, J., Tavares da Silva, C., 2004. Alterações ambientais e povoamento na transição Mesolítico-Neolítico na Costa Sudoeste. In: Tavares, A.A., Tavares, M.J.F., Cardoso, J.L. (Eds.), Evolução geohistórica do litoral português e fenómenos correlativos. Universidade Aberta, Lisboa, pp. 397-423.

Soares, J., Tavares da Silva, C., 2013. Economia agro-marítima na Pré-história do estuário do Sado. Novos dados sobre o Neolítico da Comporta. In: Soares, J. (Ed.), Pré-História das Zonas Húmidas/Prehistory of Wetlands (Setúbal Arqueológica, 14). MAEDS-ADS/ SIMARSUL, S.A, Setúbal, pp. 145-170.

Soares, J., Tavares da Silva, C., Canilho, M.H., 2005-2007. Matérias-primas minerais e 
mobilidade logística no Mesolítico da Costa Sudoeste. Os sítios de Samouqueira I e Armação Nova. Musa Museus, Arqueologia e Outros Patrimónios. 2. pp. 47-62.

Soares, J., Mazzucco, N., Tavares da Silva, C., 2017. Marine adaptations in the Late Mesolithic of the Portuguese southwest coast. Micro-use wear analysis of the lithic industry of Vale Marim I. Revista Portuguesa de Arqueologia. 20. pp. 31-44.

Straus, L., Altuna, J., Vierra, B., 1990. The Concheiro at Vidigal: a contribution to the late Mesolithic of southern Portugal. In: Vermeersch, P., van Peer, P. (Eds.), Contributions to the Mesolithic in Europe. Katholieke Universiteit, Leuven, pp. 463-474.

Tavares da Silva, C., Soares, J., 1981. Pré-história da Área de Sines. Lisboa, Gabinete da Área de Sines.

Tavares da Silva, C., Soares, J., 1997. Economias costeiras na Pré-história do Sudoeste Português. O concheiro de Montes de Baixo. Setúbal Arqueológica. 11-12. pp. 69-108.

Tavares da Silva, C., Soares, J., 2015. Neolitização da Costa Sudoeste Portuguesa. A cronologia de Vale Pincel I. In: Gonçalves, V., Diniz, M., Sousa, A.C. (Eds.), $5^{\circ}$
Congresso do Neolítico Peninsular (Estudos \& Memórias, 8). Centro de Arqueologia da Universidade de Lisboa-UNIARQ, Lisboa, pp. 645-659.

Testart, A., 1982. The significance of food storage among hunter-gatherers: residence patterns, population densities, and social inequalities. Curr. Anthropol. 23 (5), 523-537.

Van der Schriek, T., 2004. Holocene Environmental Change and the Alluvial geoarchaeology of Mesolithic Settlement-subsistence in the Muge and Magos valleys. Lower Tagus Basin, Portugal (PhD thesis). University of Newcastle upon Tyne.

Van der Schriek, T., Passmore, D.G., Mugica, F., Stevenson, A.C., Boomer, I., Rolão, J., 2008. Holocene palaeoecology and floodplain evolution of the Muge tributary, Lower Tagus Basin, Portugal. Quat. Int. 189, 135-151.

Vanney, J.-R., Mougenot, D., 1981. La plate-forme continental du Portugal et les Provinces adjacentes: analyse geomorphologique. Memórias dos Serviços, Serviços Geológicos de Portugal, Lisbon. 